\title{
1.6 Вплив піднебінних мигдаликів на стан гуморальних чинників локального імунітету в області ротоглотки у хворих на хронічні запальні захворювання верхніх дихальних шляхів при інфікуванні вірусами респіраторної групи
}

Гострі респіраторні захворювання верхніх дихальних шляхів (ВДШ), які у переважній більшості випадків обумовлені вірусами [132], особливо при частому повторенні знижують місцевий і загальний імунітет, послаблюючи специфічні і неспецифічні захисні сили організму, нерідко зумовлюють нашарування бактеріальної інфекції внаслідок активації ендогенної мікрофлори або екзогенного інфікування, що спричиняє розвитку захворювань по типу віруснобактеріальної інфекції [133]. Рецидивуючі респіраторні захворювання сприяють формуванню хронічної патології рото- та носоглотки [134], що в свою чергу підримує порушення захисних механізмів організму [135].

Мигдалики лімфаденоїдного глоткового кільця (ЛГК) виконують функцію імунологічного захисту організму, а відсутність піднебінних мигдаликів (ПМ), які беруть участь у реалізації організмом його захисної функції, негативно впливає на стан як місцевого так і системного імунітету [136].

Метою нашого дослідження було визначення ролі піднебінних мигдаликів в реалізації локальних гуморальних реакцій у хворих на хронічні запальні захворювання (Х33) ВДШ з локалізацією патологічного процесу у слизовій оболонці та лімфоутвореннях глотки - у хворих на хронічний фарингіт та хронічний тонзиліт.

Вираженість реакцій локального імунітету пацієнтів 3 хронічними запальними захворюваннями ротоглотки в стадії ремісії та у осіб контрольної групи оцінювали з урахуванням як стану ЛГК, так і наявності в крові анамнестичних противірусних антитіл (АТ) у клінічно значимих концентраціях. Присутність таких АТ розглядалась як прояв відповіді організму на вірусні антигени, з якими пацієнт активно контактував або контактує на час проведення дослідження. Обстежених осіб поділяли на таких, що мали піднебінні мигдалики, і тих, в кого вони були вилучені хірургічним шляхом за медичними 
показаннями не раніше, ніж за п’ять років до проведення дослідження.

Вивчаючи потенційний вплив контактів з респіраторними вірусами на показники локального імунітету ротової частини глотки, пацієнтів 3 наявністю або відсутністю ПМ розподіляли на таких, що мали в крові анамнестичні антитіла до одного або кількох 3 досліджених респіраторних вірусів, а саме: аденовірусу, респіраторно-синцитіального вірусу та вірусу грипу А у клінічно значимому титрі, та таких, у кого такі АТ не виявлялись. Контрольну групу склали клінічно здорові пацієнти без патології з боку ЛОР-органів.

Стан локального гуморального імунітету ротоглотки пацієнтів оцінювався за вмістом в секреті ротоглотки (СР) імунних комплексів (IК) та концентрацій секреторного імуноглобуліну А (sIgA), інтерферонів альфа ( $\alpha$-IFN) та гамма ( $\gamma$ IFN), які визначали імуноферментним методом. Всі обстежені пацієнти мали санований стан ротової порожнини.

Для статистичних розрахунків використовувався пакет ліцензійних програм STATISTICA 6.0 (Ліцензія - Free BSD). Достовірність розбіжностей отриманих даних визначалась за допомогою однобічного непараметричного критерію «U»- Манна-Уітні та критерію ф за методом кутового перетворення Фішера. Результати наводились у вигляді значень середнього арифметичного (M), медіани (Me) та квартілей (Q25-Q75). Кількість проведених досліджень позначалась як $\mathrm{n}$. При оцінці отриманих результатів порівнювались значення Ме. Достовірною вважалась розбіжність при р $<0,05$.

Важливим елементом місцевого імунітету, що захищає слизові оболонки (CO) як від заселення їх патогенними мікроорганізмами, так і від проникнення останніх до внутрішнього середовища організму, є секреторний IgA. Дослідженнями, що визначали вміст sIgA у ротоглотковому секреті хворих на хронічні запальні захворювання ротоглотки в стадії ремісії та клінічно здорових осіб в залежності від стану лімфоглоткового кільця та наявності у крові АТ до одного або кількох респіраторних вірусів, встановлено, що у практично здорових осіб контрольної групи з відсутністю піднебінних мигдаликів концентрація SIgA у секреті ротоглотки була суттєво 
зменшеною в порівнянні з такою у пацієнтів зі збереженими піднебінними мигдаликами (табл. 1).

Таблиця 1.

Вміст $\operatorname{sg}$ A у секреті ротоглотки осіб контрольної групи за наявності або відсутності у них піднебінних мигдаликів та противірусних антитіл

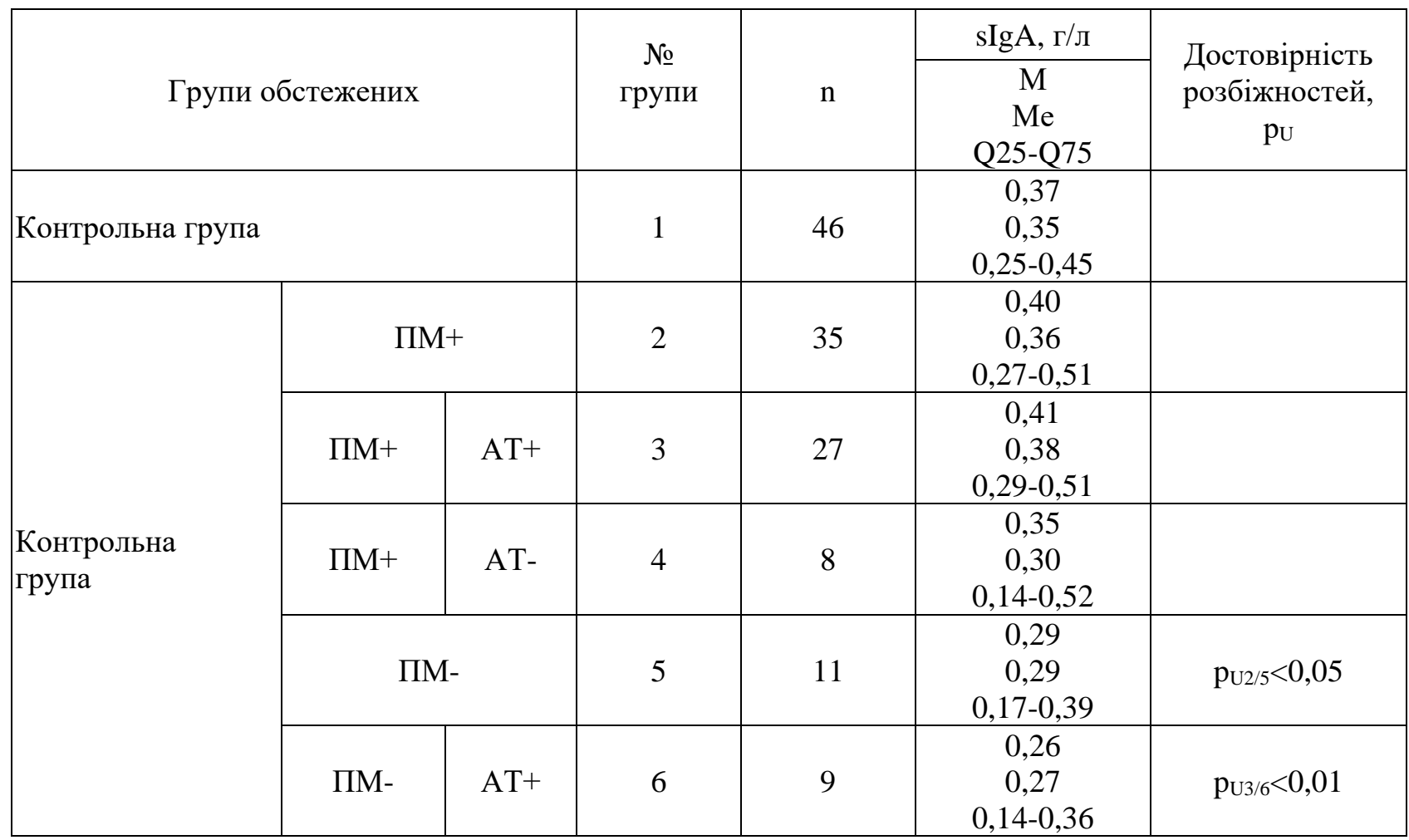

При цьому вміст $\operatorname{sg}$ А у CP тонзилектомованих пацієнтів, у яких в крові визначались противірусні АТ, був вірогідно нижче такого у обстежених осіб 3 наявністю АТ до респіраторних вірусів на тлі незміненого стану піднебінних мигдаликів.

Концентрація SIgA у РС хворих на ХЗ3 РГ суттєво не відрізнялась від такої у клінічно здорових обстежених в усіх групах порівняння (табл. 2). 
Таблиця 2.

Вміст sIgA у секреті ротоглотки хворих на хронічні запальні захворювання ротової частини глотки за наявності або відсутності піднебінних мигдаликів

та противірусних антитіл

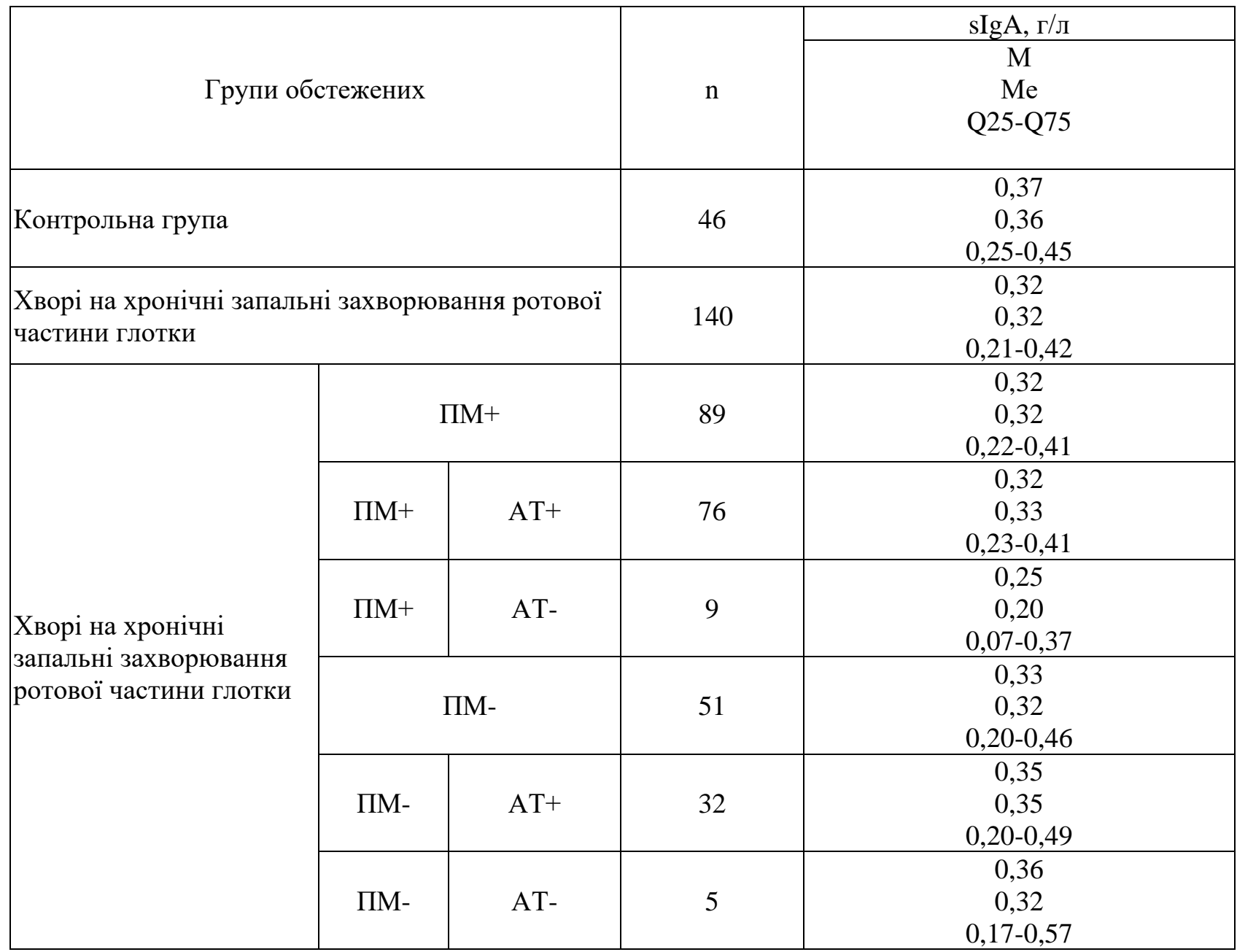

Одним 3 показників стану гуморального імунітету слизової оболонки верхніх дихальних шляхів хворих на хронічні запальні захворювання $\epsilon$ концентрація імунних комплексів в секреті ротоглотки, яка у осіб контрольної групи не змінювалась в залежності від стану ЛГК та наявності в крові обстежених противірусних АТ (табл. 3). 
Таблиця 3.

Вміст імунних комплексів у секреті ротоглотки осіб контрольної групи при різних станах ЛГК та наявності або відсутності в крові анамнестичних антитіл до вірусів респіраторної групи

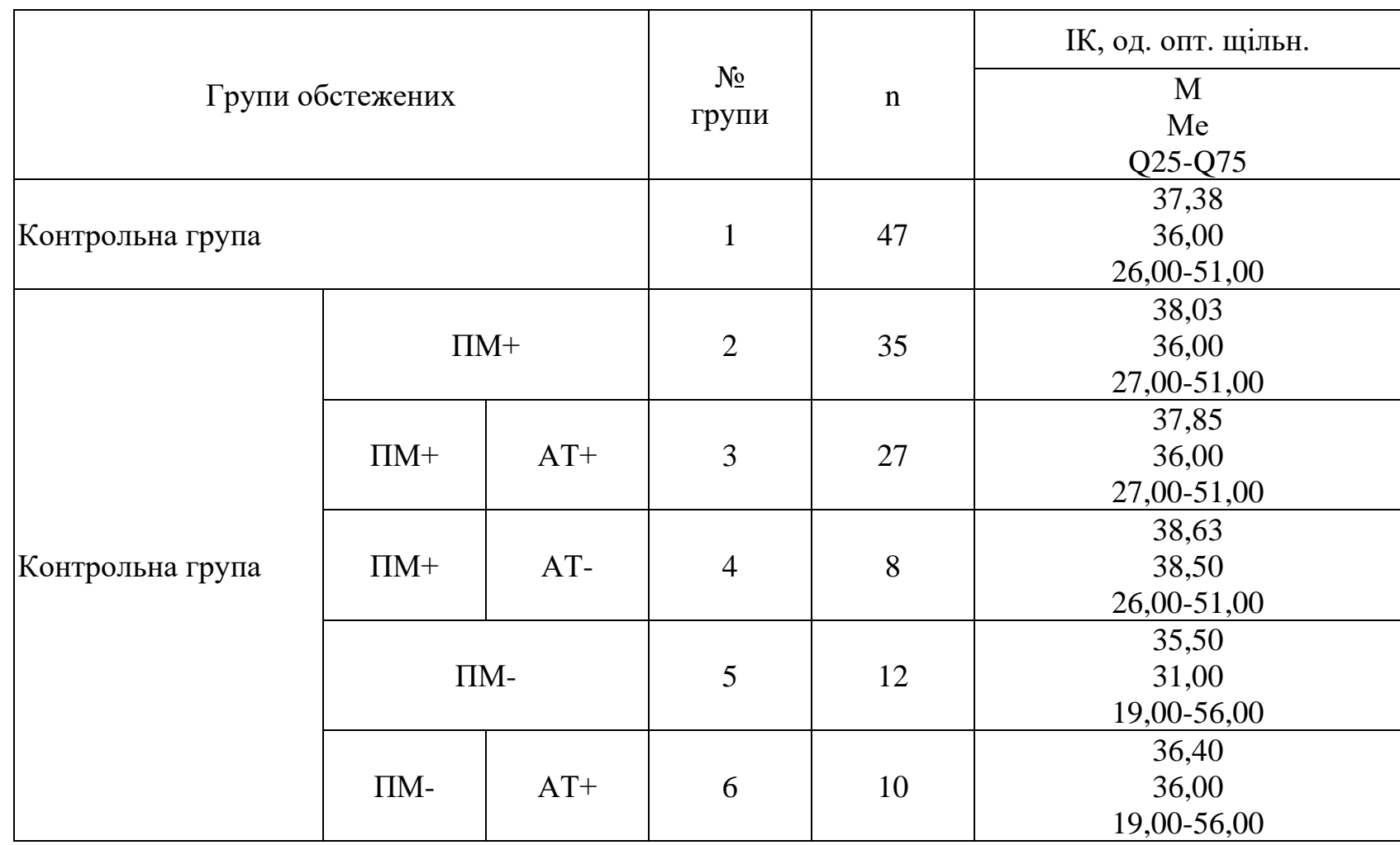

У хворих на хронічні запальні захворювання ротоглотки концентрація ІК в секреті ротоглотки була істотно зниженою в порівнянні з обстеженими із групи контролю як при наявності, так і при відсутності у них піднебінних мигдаликів (табл. 4). При цьому у тонзилектомованих осіб показники концентрації ІК були достовірно зменшеними в порівнянні з такими у обстежених контрольної групи, незалежно від вмісту у них в крові противірусних АТ. Максимально низьким вміст ІК був у секреті ротоглотки тонзилектомованих хворих, які не мали протективних титрів антитіл до вірусів респіраторної групи. 
Таблиця 4.

Вміст імунних комплексів у секреті ротоглотки хворих при різних станах лімфоглоткового кільця та в залежності від присутності в крові анамнестичних антитіл до вірусів респіраторної групи

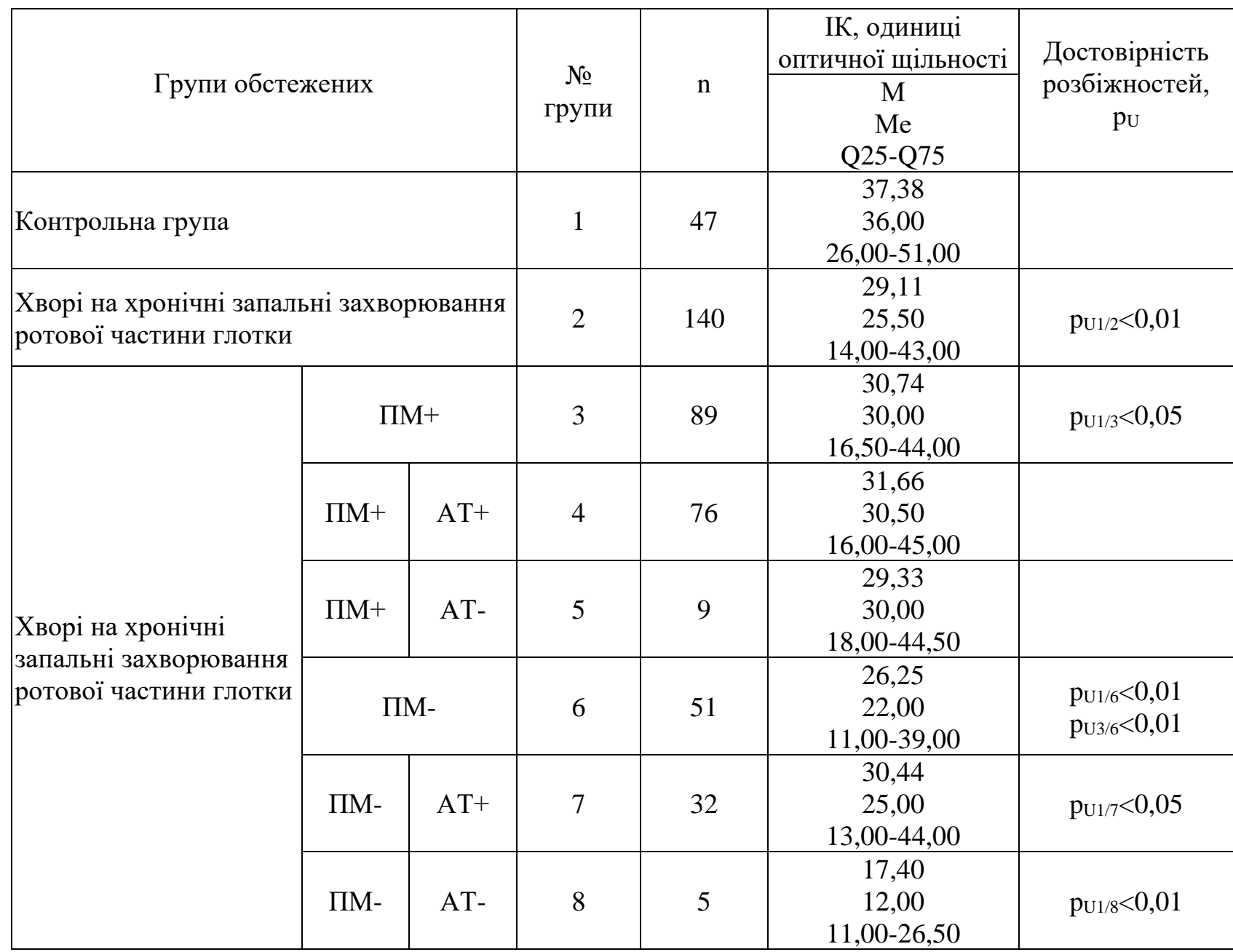

Одним із основних механізмів противірусного захисту є продукція $\alpha$-IFN ключового чинника природної неспецифічної імунної відповіді, що стримує реплікацію вірусів і дозволяє у короткі терміни мобілізувати адаптивну імунну відповідь, необхідну для елімінації інфекційного агента [137].

Проведені дослідження показали, що вміст $\alpha$-IFN в секреті ротоглотки осіб контрольної групи в більшості випадків коливався в межах нормальних значень, не відрізняючись в підгрупах в залежності від наявності в крові противірусних антитіл, проте мав тенденцію до зниження концентрації в підгрупах донорів після тонзилектомії за рахунок більшої кількості обстежених із зниженим вмістом $\alpha$-IFN (табл. 5). 
Таблиця 5.

Вміст $\alpha$-IFN у секреті ротоглотки осіб контрольної групи при різних станах лімфоглоткового кільця та наявності у крові анамнестичних противірусних антитіл

\begin{tabular}{|c|c|c|c|c|c|}
\hline \multirow{2}{*}{\multicolumn{3}{|c|}{ Групи обстежених }} & \multirow[b]{2}{*}{$\begin{array}{c}\text { № } \\
\text { групи }\end{array}$} & \multirow[b]{2}{*}{$\mathrm{n}$} & $\alpha$-IFN, пг/л \\
\hline & & & & & $\begin{array}{c}\mathrm{M} \\
\mathrm{Me} \\
\mathrm{Q} 25-\mathrm{Q} 75\end{array}$ \\
\hline \multicolumn{3}{|l|}{ Контрольна група } & 1 & 24 & $\begin{array}{c}56,62 \\
46,85 \\
24,25-66,70\end{array}$ \\
\hline \multirow{5}{*}{ Контрольна група } & \multicolumn{2}{|c|}{ ПМ+ } & 2 & 15 & $\begin{array}{c}64,85 \\
47,80 \\
25,60-62,20\end{array}$ \\
\hline & ПМ+ & $\mathrm{AT}+$ & 3 & 9 & $\begin{array}{c}58,17 \\
52,20 \\
24,50-84,80 \\
\end{array}$ \\
\hline & ПМ+ & AT- & 4 & 6 & $\begin{array}{c}74,87 \\
31,05 \\
25,60-47,80\end{array}$ \\
\hline & \multicolumn{2}{|c|}{ ПМ- } & 5 & 9 & $\begin{array}{c}42,91 \\
45,90 \\
13,30-71,35\end{array}$ \\
\hline & ПМ- & $\mathrm{AT}+$ & 6 & 7 & $\begin{array}{c}43,71 \\
45,90 \\
16,60-71,20\end{array}$ \\
\hline
\end{tabular}

Аналогічна закономірність спостерігалась і при визначенні рівня $\alpha$-IFN у тонзилектомованих хворих на хронічні запальні захворювання ротоглотки, яка досягала статистично значущої різниці порівняно з показниками вмісту $\alpha$-IFN у осіб контрольної групи (табл. 6).

Найбільшою мірою зменшення концентрації $\alpha$-IFN визначено у пацієнтів із видаленими піднебінними мигдаликами та відсутністю в крові анамнестичних антитіл проти вірусів респіраторної групи, у яких рівень $\alpha$-IFN в секреті ротоглотки був суттєво менший за такий у осіб контрольної групи та хворих на X33 РГ з не видаленими піднебінними мигдаликами, концентрація $\alpha$-IFN в CP яких суттєво не відрізнялась від такої у осіб контрольної групи (табл. 5 та 6). 
Таблиця 6.

Вміст $\alpha$-IFN у секреті ротоглотки хворих при різних станах лімфоглоткового кільця та наявності у крові антитіл до вірусів респіраторної групи

\begin{tabular}{|c|c|c|c|c|c|c|}
\hline \multirow{2}{*}{\multicolumn{3}{|c|}{ Групи обстежених }} & \multirow[b]{2}{*}{$\begin{array}{c}\text { № } \\
\text { групи }\end{array}$} & \multirow[b]{2}{*}{$\mathrm{n}$} & $\alpha$-IFN, пг/л & \multirow[b]{2}{*}{$\begin{array}{c}\text { Достовірність } \\
\text { розбіжностей, } \\
\mathrm{p}_{\mathrm{U}}\end{array}$} \\
\hline & & & & & $\begin{array}{c}\mathrm{M} \\
\mathrm{Me} \\
\mathrm{Q} 25-\mathrm{Q} 75\end{array}$ & \\
\hline \multicolumn{3}{|l|}{ Контрольна група } & 1 & 24 & $\begin{array}{c}56,62 \\
46,85 \\
24,25-66,70\end{array}$ & \\
\hline \multicolumn{3}{|c|}{$\begin{array}{l}\text { Хворі на хронічні запальні захворювання } \\
\text { ротової частини глотки }\end{array}$} & 2 & 59 & $\begin{array}{c}45,26 \\
26,90 \\
15,80-60,60\end{array}$ & \\
\hline \multirow{6}{*}{$\begin{array}{l}\text { Хворі на хронічні } \\
\text { запальні } \\
\text { захворювання } \\
\text { ротової частини } \\
\text { глотки }\end{array}$} & \multicolumn{2}{|c|}{ ПМ+ } & 3 & 40 & $\begin{array}{c}51,15 \\
36,40 \\
17,80-63,50 \\
\end{array}$ & \\
\hline & ПМ+ & $\mathrm{AT}+$ & 4 & 34 & $\begin{array}{c}49,35 \\
41,55 \\
19,10-66,40 \\
\end{array}$ & \\
\hline & ПМ+ & AT- & 5 & 4 & $\begin{array}{c}13,85 \\
15,10 \\
5,20-20,00 *\end{array}$ & $\begin{array}{l}\mathrm{p}_{\mathrm{U} 1 / 5}<0,01 \\
\mathrm{p}_{\mathrm{U} 4 / 5}<0,05\end{array}$ \\
\hline & \multicolumn{2}{|c|}{ ПМ- } & 6 & 19 & $\begin{array}{c}32,86 \\
22,20 \\
11,40-36,40\end{array}$ & $\mathrm{p}_{\mathrm{U} 1 / 6}<0,05$ \\
\hline & ПМ- & $\mathrm{AT}+$ & 7 & 14 & $\begin{array}{c}40,93 \\
24,00 \\
17,60-77,30\end{array}$ & \\
\hline & ПМ- & AT- & 8 & 5 & $\begin{array}{c}10,26 \\
11,10 \\
0,95-19,15\end{array}$ & $\begin{array}{l}\mathrm{p}_{\mathrm{U} 1 / 8}<0,01 \\
\mathrm{p}_{\mathrm{U} 7 / 8}<0,01\end{array}$ \\
\hline
\end{tabular}

Примітка: * - межі коливань .

Проведені дослідження показали, що концентрація $\alpha$-IFN в секреті ротоглотки залежить також від інфікованості обстежених пацієнтів різних груп вірусами респіраторної групи. Зокрема, у хворих на хронічні запальні захворювання ВДШ з відсутністю противірусних антитіл рівень $\alpha$-IFN в секреті ротоглотки був суттєво нижчим за аналогічні показники у здорових осіб та в підгрупах обстежених 3 клінічно значущими титрами антитіл проти респіраторних вірусів незалежно від наявності або відсутності у них піднебінних мигдаликів (табл. 5 та 6). 
Визначення концентрації $\gamma$-IFN, який зв'язується зі спеціальними рецепторами клітин і впливає на процес репродукції вірусу всередині клітини на стадії синтезу білків, проявляючи імуномодулюючу активність та залучаючи різні клітини імунної системи до регуляції гомеостазу організму [138], показало, що його вміст в секреті ротоглотки осіб контрольної групи суттєво відрізнявся в залежності від наявності або відсутності у них піднебінних мигдаликів і був вірогідно зменшеним у раніше тонзилектомованих пацієнтів (табл. 7).

Таблиця 7

Вміст $\gamma$-IFN у секреті рото глотки осіб контрольної групи за наявності або відсутності у них піднебінних мигдаликів

\begin{tabular}{|c|c|c|c|c|c|c|}
\hline \multirow{2}{*}{\multicolumn{3}{|c|}{ Групи обстежених }} & \multirow[b]{2}{*}{$\begin{array}{c}\text { № } \\
\text { групи }\end{array}$} & \multirow[b]{2}{*}{$\mathrm{n}$} & $\gamma$-IFN, пг/мл & \multirow[b]{2}{*}{$\begin{array}{c}\text { Достовірність } \\
\text { розбіжностей, } \\
\mathrm{p}_{\mathrm{U}}\end{array}$} \\
\hline & & & & & $\begin{array}{c}\mathrm{M} \\
\mathrm{Me} \\
\mathrm{Q} 25-\mathrm{Q} 75\end{array}$ & \\
\hline \multicolumn{3}{|l|}{ Контрольна група } & 1 & 24 & $\begin{array}{c}667,60 \\
306,9 \\
181,45-1173,00\end{array}$ & \\
\hline \multirow{4}{*}{ Контрольна група } & \multicolumn{2}{|c|}{ ПМ+ } & 2 & 15 & $\begin{array}{c}873,89 \\
451,00 \\
104,40-1564,00\end{array}$ & \\
\hline & ПМ+ & AT + & 3 & 9 & $\begin{array}{c}671,68 \\
311,40 \\
80,90-1328,50\end{array}$ & \\
\hline & \multicolumn{2}{|c|}{ ПМ- } & 5 & 9 & $\begin{array}{c}323,77 \\
261,40 \\
181,45-296,80\end{array}$ & $\mathrm{p}_{\mathrm{U} 2 / 5}<0,05$ \\
\hline & ПМ- & $\mathrm{AT}+$ & 6 & 7 & $\begin{array}{c}364,49 \\
261,40 \\
191,80-302,50 \\
\end{array}$ & \\
\hline
\end{tabular}

У хворих на хронічні запальні захворювання ротової частини глотки вміст $\gamma$-IFN не залежав від наявності або відсутності піднебінних мигдаликів і в середньому достовірно не відрізнявся від такого у не тонзилектованих осіб контрольної групі. Разом з тим, звертає увагу значне збільшення концентрації $\gamma$ IFN в секреті ротоглотки хворих зі збереженими ПМ, які не мали контакту 3 вірусами респіраторної групи, хоча цей факт потребує додаткового дослідження в зв'язку з невеликою кількістю спостережень (табл. 8). 
Таблиця 8

Вміст $\gamma$-IFN у секреті ротоглотки хворих при наявності або відсутності у них піднебінних мигдаликів та противірусних антитіл

\begin{tabular}{|c|c|c|c|c|c|c|}
\hline \multirow{2}{*}{\multicolumn{3}{|c|}{ Групи обстежених }} & \multirow[b]{2}{*}{$\begin{array}{c}\text { № } \\
\text { групи }\end{array}$} & \multirow[b]{2}{*}{$\mathrm{n}$} & $\gamma$-IFN, пг/мл & \multirow{2}{*}{$\begin{array}{c}\text { Достовірність } \\
\text { розбіжностей, } \\
\text { pu }\end{array}$} \\
\hline & & & & & $\begin{array}{c}\mathrm{M} \\
\mathrm{Me} \\
\mathrm{Q} 25-\mathrm{Q} 75\end{array}$ & \\
\hline \multicolumn{3}{|l|}{ Контрольна група } & 1 & 24 & $\begin{array}{c}667,60 \\
306,9 \\
181,45-1173,00 \\
\end{array}$ & \\
\hline \multicolumn{3}{|c|}{$\begin{array}{l}\text { Хворі на хронічні запальні захворювання } \\
\text { ротової частини глотки }\end{array}$} & 2 & 58 & $\begin{array}{c}763,14 \\
300,05 \\
135,50-1316,00\end{array}$ & \\
\hline \multirow{6}{*}{$\begin{array}{l}\text { Хворі на хронічн } \\
\text { захворювання ро } \\
\text { частини глотки }\end{array}$} & \multicolumn{2}{|c|}{ ПМ+ } & 3 & 39 & $\begin{array}{c}752,05 \\
249,60 \\
147,40-1317,00 \\
\end{array}$ & \\
\hline & ПМ+ & $\mathrm{AT}+$ & 4 & 33 & $\begin{array}{c}696,23 \\
233,30 \\
141,45-1316,50 \\
\end{array}$ & \\
\hline & ПМ+ & AT- & 5 & 4 & $\begin{array}{c}1334,68 \\
1403,50 \\
609,70-1922,00^{*}\end{array}$ & $\begin{array}{l}\mathrm{p}_{\mathrm{U} 1 / 5}<0,05 \\
\mathrm{p}_{\mathrm{U} 4 / 5}<0,05\end{array}$ \\
\hline & \multicolumn{2}{|c|}{ ПМ- } & 6 & 19 & $\begin{array}{c}785,40 \\
314,40 \\
107,40-1290,00\end{array}$ & \\
\hline & ПМ- & $\mathrm{AT}+$ & 7 & 14 & $\begin{array}{c}790,60 \\
300,05 \\
107,40-1290,00 \\
\end{array}$ & \\
\hline & ПМ- & AT- & 8 & 5 & $\begin{array}{c}772,72 \\
573,10 \\
164,25-1481,00\end{array}$ & \\
\hline
\end{tabular}

Примітка: * - межі коливань.

Проведені дослідження показали, що структури лімфоглоткового кільця відіграють суттєву роль у формуванні реакцій місцевого імунітету. Отримані результати свідчать про те, що вміст $\operatorname{sg} \mathrm{A}, \alpha$-IFN та $\gamma$-IFN в секреті ротоглотки залежить від піднебінних мигдаликів, зменшуючись у обстежених осіб контрольної групи, які зазнали тонзилектомії. Хронічні запальні захворювання верхніх дихальних шляхів спричиняють зменшення концентрації IK та $\alpha$-IFN в секреті ротоглотки хворих з різним станом піднебінних мигдаликів. Проте у пацієнтів 3 нормальним станом піднебінних мигдаликів, які перехворіли вірусними інфекціями, на відміну від осіб із видаленими піднебінними мигдаликами, показники вмісту $\alpha$-IFN збільшуються, практично не 
відрізняючись від таких у практично здорових донорів. Найбільше пригнічення продукції IК та $\alpha$-IFN визначається у хворих на хронічні запальні захворювання верхніх дихальних шляхів 3 видаленими піднебінними мигдаликами та 3 відсутністю клінічно значимих титрів противірусних антитіл.

Таким чином, дослідження показників місцевого імунітету у хворих на хронічні запальні захворювання верхніх дихальних шляхів 3 різним станом піднебінних мигдаликів, що контактують або мали контакт з респіраторними вірусами, надає можливість виявити найбільш вразливі ланки в системі їх протиінфекційного захисту, на які перш за все варто звертати увагу при обстеженні та лікуванні пацієнтів з хронічними запальними захворюваннями верхніх дихальних шляхів, особливо при умові частого повторення у них гострих респіраторних захворювань. 